\title{
Alcohol-induced liver injury: how a small molecule overwhelms one of the cell types with the best regeneration capacity of the human body
}

\author{
Jan G. Hengstler $\cdot$ Patricio Godoy $•$ Joanna D. Stewart $•$ \\ Hermann M. Bolt
}

Published online: 21 May 2009

(C) Springer-Verlag 2009

One of the outstanding features of the liver is its enormous regeneration capacity that has evolved to protect animals from liver loss by food toxins (Michalopoulos and DeFrances 1997). The best known experimental system for the study of the regenerating liver is a simple operation in which twothirds of the liver of a rat or mouse is removed. The residual lobes enlarge and within only 7 days make up for the mass of the removed tissue. Furthermore, after intoxication with chemicals such as $\mathrm{CCl}_{4}$ that can kill up to $50 \%$ of the hepatocytes, regeneration also results in complete restoration of intact liver tissue (Höhme et al. 2007; Brulport et al. 2007; Aurich et al. 2007). In addition in larger animals and humans, the regeneration capacity of the liver is excellent. Another experimental system to study the liver regeneration is that of mice deficient in fumarylaetoacetate hydrolase causing a permanent deterioration of hepatocytes and finally death of the animal (review: Hengstler et al. 2005). Hepatocytes transplanted into these livers colonize and rescue the entire organ (review: Nussler et al. 2006). Hepatocytes from the rescued livers can be transplanted in second generation livers, and so forth. Using this approach of serial transplantation, it has been shown that a single hepatocyte has the clonogenic capacity to form at least 50 livers (Overturf et al. 1996). Besides its amazing regenerative capacity, the liver is characterized by its outstanding

J. G. Hengstler $(\bowtie) \cdot$ P. Godoy · J. D. Stewart · H. M. Bolt Leibniz-Institut für Arbeitsforschung an der TU Dortmund, Leibniz Research Centre for Working Environment and Human Factors (IfADo), Ardeystrasse 67, 44139 Dortmund, Germany e-mail: hengstler@ifado.de capability to adapt to new situations. When livers from baboons were transplanted into humans, the size of the transplanted liver rapidly increased (reviewed in: Michalopoulos and DeFrances 1997).Vice versa livers from large dogs transplanted into small dogs gradually decreased in size until it reached an adequate volume to the smaller body size. It is difficult to comprehend how an organ with such an amazing regeneration and adaptation capacity can be overwhelmed by the relatively low and nontoxic ethanol concentrations resulting from drinking alcohol. Nevertheless, alcohol consumption is the major cause of liver disease in Western countries. An initial fatty acid change or steatosis, characterized by fat globules (macrovesicular steatosis) may lead to an inflammatory reaction, alcoholic hepatitis. Both, steatosis and alcoholic hepatitis may be reversible. In contrast, the late stage, cirrhosis, marked by fibrosis and compromised liver architecture is irreversible. One of the most important mechanisms causing alcoholic liver disease is the generation of oxidative stress, which is a cutting edge topic of our journal (Adam and Laufs 2008; Verstraeten et al. 2008; Bolt and Hengstler 2008; Glahn et al. 2008; Helal and Helal 2009; Beyersmann and Hartwig 2008; Arivarasu et al. 2008; Matés et al. 2008; Hengstler and Bolt 2007, 2008; Abe et al. 2008; Nishimura et al. 2008; Kolli et al. 2008; McDermott et al. 2008; Manna et al. 2008; Sivalingam et al. 2008; Schug et al. 2008; Binner et al. 2008; Dika Nguea et al. 2008). The editors are happy that Dr. Arthur I. Cederbaum, Mount Sinai School of Medicine, New York has contributed a comprehensive review about the role of oxidative stress in alcohol-induced liver injury. The authors discuss the role of Kupffer cells, lipid peroxidation, formation of the 1-hydroxyethyl radical, $S$-adenosyl-L-methionine, NO production and protein adducts. Special emphasis is placed on the role of CYP2E1 in generating reactive-oxygen species. 


\section{References}

Abe M, Usuda K, Hayashi S, Ogawa I, Furukawa S, Igarashi M, Nakae D (2008) Carcinogenic risk of copper gluconate evaluated by a rat medium-term liver carcinogenicity bioassay protocol. Arch Toxicol 82:563-571

Adam O, Laufs U (2008) Antioxidative effects of statins. Arch Toxicol $82: 885-892$

Arivarasu NA, Fatima S, Mahmood R (2008) Oral administration of potassium dichromate inhibits brush border membrane enzymes and alters anti-oxidant status of rat intestine. Arch Toxicol 82:951-958

Aurich I, Mueller LP, Aurich H, Luetzkendorf J, Tisljar K, Dollinger MM, Schormann W, Walldorf J, Hengstler JG, Fleig WE, Christ B (2007) Functional integration of hepatocytes derived from human mesenchymal stem cells into mouse livers. Gut 56:405-415

Beyersmann D, Hartwig A (2008) Carcinogenic metal compounds: recent insight into molecular and cellular mechanisms. Arch Toxicol 82:493-512

Binner C, Selinski S, Barysch MJ, Pölcher C, Schormann W, Hermes M, Brulport M, Bauer A, Rudolph C, Bedawy E, Schug M, Golka K, Hasenclever D, Trauer H, Lessig R, Bolt HM, Ickstadt K, Hengstler JG (2008) Munich Oktoberfest experience: remarkable impact of sex and age in ethanol intoxication. Arch Toxicol 82:933-939

Bolt HM, Hengstler JG (2008) Aluminium and lead toxicity revisited: mechanisms explaining the particular sensitivity of the brain to oxidative damage. Arch Toxicol 2008(82):787-788

Brulport M, Schormann W, Bauer A, Hermes M, Elsner C, Hammersen FJ, Beerheide W, Spitkovsky D, Härtig W, Nussler A, Horn LC, Edelmann J, Pelz-Ackermann O, Petersen J, Kamprad M, von Mach M, Lupp A, Zulewski H, Hengstler JG (2007) Fate of extrahepatic human stem and precursor cells after transplantation into mouse livers. Hepatology 46:861-870

Dika Nguea H, de Reydellet A, Lehuédé P, De Meringo A, Le Faou A, Marcocci L, Rihn BH (2008) Gene expression profile in monocyte during in vitro mineral fiber degradation. Arch Toxicol $82: 355-362$

Glahn F, Schmidt-Heck W, Zellmer S, Guthke R, Wiese J, Golka K, Hergenröder R, Degen GH, Lehmann T, Hermes M, Schormann W, Brulport M, Bauer A, Bedawy E, Gebhardt R, Hengstler JG, Foth H (2008) Cadmium, cobalt and lead cause stress response, cell cycle deregulation and increased steroid as well as xenobiotic metabolism in primary normal human bronchial epithelial cells which is coordinated by at least nine transcription factors. Arch Toxicol 82:513-524

Helal GK, Helal OK (2009) Metallothionein attenuates carmustineinduced oxidative stress and protects against pulmonary fibrosis in rats. Arch Toxicol 83:87-94

Hengstler JG, Bolt HM (2007) Induction and control of oxidative stress. Arch Toxicol 81:823-824
Hengstler JG, Bolt HM (2008) Oxidative stress: from modification of cell-cycle related events, secondary messenger function, dysregulation of small GTPases, protein kinases and phosphatases to redox-sensitive cancer models. Arch Toxicol 82:271-272

Hengstler JG, Brulport M, Schormann W, Bauer A, Hermes M, Nussler AK, Fandrich F, Ruhnke M, Ungefroren H, Griffin L, Bockamp E, Oesch F, von Mach MA (2005) Generation of human hepatocytes by stem cell technology: definition of the hepatocyte. Expert Opin Drug Metab Toxicol 1:61-74

Höhme S, Hengstler JG, Brulport M, Schäfer M, Bauer A, Gebhardt R, Drasdo D (2007) Mathematical modelling of liver regeneration after intoxication with $\mathrm{CCl}(4)$. Chem Biol Interact 168:74-93

Kolli VK, Abraham P, Rabi S (2008) Methotrexate-induced nitrosative stress may play a critical role in small intestinal damage in the rat. Arch Toxicol 82:763-770

Manna P, Sinha M, Sil PC (2008) Arsenic-induced oxidative myocardial injury: protective role of arjunolic acid. Arch Toxicol 82:137-149

Matés JM, Segura JA, Alonso FJ, Márquez J (2008) Intracellular redox status and oxidative stress: implications for cell proliferation, apoptosis, and carcinogenesis. Arch Toxicol 82:273-299

McDermott C, O’Donoghue MH, Heffron JJ (2008) n-Hexane toxicity in Jurkat T-cells is mediated by reactive oxygen species. Arch Toxicol 82:165-171

Michalopoulos GK, DeFrances MC (1997) Liver regeneration. Science 276:60-66

Nishimura J, Dewa Y, Okamura T, Muguruma M (2008) Possible involvement of oxidative stress in fenofibrate-induced hepatocarcinogenesis in rats. Arch Toxicol 82:641-654

Nussler A, Konig S, Ott M, Sokal E, Christ B, Thasler W, Brulport M, Gabelein G, Schormann W, Schulze M, Ellis E, Kraemer M, Nocken F, Fleig W, Manns M, Strom SC, Hengstler JG (2006) Present status and perspectives of cell-based therapies for liver diseases. J Hepatol 45:144-459

Overturf K, Al-Dhalimy M, Tanguay R, Brantly M, Ou CN, Finegold M, Grompe M (1996) Hepatocytes corrected by gene therapy are selected in vivo in a murine model of hereditary tyrosinaemia type I. Nat Genet 12:266-273

Schug M, Heise T, Bauer A, Storm D, Blaszkewicz M, Bedawy E, Brulport M, Geppert B, Hermes M, Föllmann W, Rapp K, Maccoux L, Schormann W, Appel KE, Oberemm A, GundertRemy U, Hengstler JG (2008) Primary rat hepatocytes as in vitro system for gene expression studies: comparison of sandwich, Matrigel and 2D cultures. Arch Toxicol 82:923-931

Sivalingam N, Basivireddy J, Balasubramanian KA, Jacob M (2008) Curcumin attenuates indomethacin-induced oxidative stress and mitochondrial dysfunction. Arch Toxicol 82:471-481

Verstraeten SV, Aimo L, Oteiza PI (2008) Aluminium and lead: molecular mechanisms of brain toxicity. Arch Toxicol 82:789802 